\title{
Phenotypic and genotypic profile of Enterobacteria resistant to beta- lactams
}

\author{
Andressa Liberal Santos \\ Universidade Federal de Goias \\ Adailton Pereira dos Santos \\ Universidade Federal de Goias \\ Célia Regina Malveste Ito \\ Universidade Federal de Goias \\ Pedro Henrique Pereira de Queiroz \\ Universidade Federal de Goias \\ Juliana Afonso de Almeida \\ Universidade Federal de Goias \\ Marcos Antonio Batista de Carvalho Junior \\ Universidade Federal de Goias \\ Camila Zanatta de Oliveira \\ Universidade Federal de Goias \\ Melissa Ameloti G Avelino \\ Universidade Federal de Goias \\ Isabela Jubé Wastowski \\ Universidade Estadual de Goias \\ Giselle Pinheiro Lima Aires Gomes \\ Universidade Federal de Goias \\ Adenícia Custódia Silva e Souza \\ Pontificia Universidade Catolica de Goias \\ Lara Stefânia Netto de Oliveira Leão Vasconcelos \\ Universidade Federal de Goias \\ Mônica de Oliveira Santos \\ Universidade Federal de Goias \\ Carla Afonso da Silva Bitencourt Braga \\ Universidade Federal de Goias \\ Mônica Santiago Barbosa \\ Universidade Federal de Goias \\ Lilian Carla Carneiro ( $\square$ carlacarneirolilian@gmail.com ) \\ Universidade Federal de Goias https://orcid.org/0000-0003-4067-1506
}

\section{Research article}

Keywords: Antibiogram, Antimicrobial Resistance, $\beta$-lactams, Enterobacterias, Molecular Diagnosis.

Posted Date: September 9th, 2019

DOI: https://doi.org/10.21203/rs.2.14194/v1

License: (1) This work is licensed under a Creative Commons Attribution 4.0 International License. Read Full License 


\section{Abstract}

Background: A serious emerging problem worldwide is increased antimicrobial resistance. Acquisition of coding genes for evasion methods of antimicrobial drug mechanisms characterizes acquired resistance. This phenomenon has been observed in several bacteria, including major species of Gram-negative bacteria such as the Enterobacteriaceae family. Among these, strains resistant to multiple classes of antibiotics were observed. Treatment for bacterial infections is performed with antibiotics and among the most used betalactams stand out. Resistance to this class of antimicrobials has also increased. The aim of this study was to correlate antimicrobial resistance profiles in Enterobacteriaceae by phenotypic methods and molecular identification of 14 beta-lactamase coding genes: blaOXA; blaIMP; blaNDM; blaSME; blaDHA; blaCMY, blaTEM, blaKPC, blaSPM, blaCTX-M, blaVIM, blaSIM, blaGIM, and blaSHV.

Methods: The phenotypic methodologies used were the Antimicrobial Sensitivity Test for Disk-Diffusion, and complementary tests for the detection of resistance mechanisms of beta-lactamases (ESBL, MBL, AmpC and Carbapenemase). The molecular methodology used was Real Time PCR using the Sybr Green system.

Results: Among the results found in the tests it was observed that $74.28 \%$ were resistant to ampicillin, $34.28 \%$ were resistant to aztreonam, $62.85 \%$ were resistant to amoxicillin associated with clavalunate, $51.42 \%$ were resistant to ceftazidime, $41.42 \%$ were resistant to cefoxitin, $54.28 \%$ were resistant to cefazolin, $44.28 \%$ were resistant to cefepime, $41.42 \%$ were resistant to cefuroxime, $8.57 \%$ were resistant to cefuroxime, $35.71 \%$ were resistant an imipenem and $41.42 \%$ were resistant to piperacillin associated with tazobactam. Among the total samples, the mechanism of resistance that presented the highest expression was ESBL (17.14\%). The genes studied that were detected in a greater number of species were blaGIM and blaSIM (66.66\% of the samples). The gene that was amplified in a smaller number of samples was blaVIM (16.66\%).

Conclusions: It is concluded that although there is a low correlation between the methodologies analyzed, the levels of antimicrobial resistance in enterobacteria are high and worrying, and a way to minimize the accelerated emergence of resistance includes the development or improvement of techniques that generate diagnoses with high efficiency and speed.

\section{Background}

Currently, in relation to taxonomy, the Enterobacteriacea family has 53 genera of which more than 170 species have already been named. Among these, 26 bacterial genera have already been associated with bacterial infections in humans. Members of this family are small gram-negative, facultative anaerobic rods and most species are able to grow at $37^{\circ} \mathrm{C}$, although some grow more properly at 25 to $30{ }^{\circ} \mathrm{C}$ (1).

These microorganisms are widely distributed in nature and are found in soil, water, vegetables, in the intestinal tract of humans and vertebrates (2). Enterobacteriaceae represent the main group of bacteria isolated in clinical samples and are associated with a wide variety of community and hospital infections (3). Gram-negative bacteria, specifically Enterobacteriaceae, are common causes of both community-acquired and hospital acquired infections, including urinary tract, bloodstream, and lower respiratory tract infections (4).

Resistance among clinically important organisms to antimicrobial agents is severely threatening the repertoire of treatment options for common infections. The challenge is intensified by the fact that several of these organisms are resistant to multiple antimicrobials (5). Infections caused by Gram-negative bacteria resistant to multiple drugs are a serious public health problem due to the scarcity of treatment options for these infections (6).

Antibiotics play a key role in the success of some medical practices. Unfortunately they tend to lose their efficacy over time due to the emergence and spread of resistance among bacterial pathogens (7).

Drug resistance genes can be spread from one bacterium to another through various mechanisms such as plasmids, bacteriophages, naked DNA or transposons. Some transposons contain integrons-more complex transposons that contain a site for integrating different antibiotic resistance genes and other gene cassettes in tandem for expression from a single promoter (8).Bacterial conjugation is the most sophisticated form of horizontal gene transfer (HGT) in bacteria and provides a platform for the spread and persistence of antibiotic resistance and virulence genes (9).

Beta-lactams are preferred because of their clinical efficacy and safety by virtue of their high selective toxicity (10). Resistance to betalactams in Enterobacteriaceae and other Gram-negative organisms is primarily mediated by beta-lactamases (11). Beta-lactamases are enzymes that catalyze the hydrolysis of the beta-lactam ring inactivating the antimicrobial and preventing it from being active against the enzymes responsible for bacterial cell wall synthesis (12). 
Antimicrobial susceptibility testing methods are divided into types based on the principle applied in each system (13). The antibiogram provides qualitative results by categorizing bacteria as susceptible, resistant intermediate or resistant. Therefore, it is a tool based on the resistance phenotype of the tested microbial strain. However, inhibition of bacterial growth does not mean bacterial killing, the phenotypic method fails to distinguish between bactericidal and / or bacteriostatic effects (14).

Molecular diagnosis is another method of identifying bacterial resistance that can be applied. The molecular technique performed through nucleic acids, while requiring advancements, may allow a patient to obtain the result of an examination rapidly, within a four-hour period; thus, initiating the most appropriate antibiotic therapy. This can improve treatment outcomes for the patient and reduce empirical antimicrobial prescriptions, decreasing the duration and cost of antimicrobial treatment. Thus, technologies with the diagnosis of nucleic acids have the potential to reduce the selection of new resistances as well as to reduce the potential of existing resistances (15).

The objectives of this study are to correlate the resistance profiles of Enterobacteria using phenotypic and genotypic methodologies. The genes encoding resistance to beta-lactams are: blaSPM, blaSIM, blaVIM, blaKPC, blaSHV, blaCTX-M, blaGIM, blaOXA, blaIMP, blaNDM, blaSME, blaDHA, blaCMY and blaTEM. This study is justified because it is assumed that molecular methods improve accuracy, efficiency and accuracy compared to the classical phenotyping method. In addition, it can be released in a short time; helping to improve the effectiveness of antibiotic therapy.

\section{Methods}

A total of 70 bacterial samples of Enterobacteriaceaewere stored in a bio-repository at the Laboratory. Among the analyzed bacteria are the species: Klebsiella pneumoniae, Proteus mirabilis, Citrobacter freundii, Morganella morgani, Providencia spp., Enterobacter aerogenes, Enterobacter agglomerans, Raoultella terrigenes, Escherichia coli, Escherichia blatteae, Edwarsiella ictaluri, Cedecea neteri, Erwinia persicina, Providencia rustigiani, Salmonella paratyphia, Salmonella typhi, Yersinia ruckeri, Serratia marcecens and Hafnia alvei. Bacteria come from mucosa of human tonsils (five samples), human corneas (twenty three samples), animal bladder (four samples), animal uterus (ten samples), Veterinary Hospital Environment (twenty one samples) as well as respiratory equipment from a hospital service, Manual Resuscitators - MRI (seven samples). The isolates of human tonsils originated from Hospital of the clinics of the Federal University of Goiás, Brazil; human corneas from the Service of Verification of Deaths (SVO) of Goiânia, Goiás, Brazil; the animal bladder and uterus samples were obtained from a female dog hospitalized veterinary hospital of Goiânia, Goiás, Brazil; veterinary hospital environment samples came from the Dog Center clinic in Goiânia, Goiás, Brazil and manual resuscitators from an Intermediate Care Unit (ICU) of a public hospital in the state of Tocantins, Brazil.

After being stored as a biorrepository, these enterobacteria were randomly used in this study to compare the resistance profile presented by both phenotypic and genotypic methodology.

The antibiogram and sensitivity of the Gram-negative bacilli samples to the various antimicrobials were performed according to agardiffusion methodology (Kirby-Bauer), according to the bacterial genus were used the antimicrobials ampicillin $30 \mu \mathrm{g}$, amoxilineclavulanate $20 / 10 \mu \mathrm{g}$, aztreonam $30 \mu \mathrm{g}$, cefazolin $30 \mu \mathrm{g}$, cefepime $30 \mu \mathrm{g}$, cefoxitin $30 \mu \mathrm{g}$, cefuroxime $30 \mu \mathrm{g}$, ceftazidime $30 \mu \mathrm{g}$; ceftriaxone 30 , imipen $10 \mu \mathrm{g}$ and piperacillin-tazobactam $100 / 10 \mu \mathrm{g}$. As a quality control, strains $E$. coli ATCC ${ }^{\circledR} 35218$ were used for combinations of $\beta$-lactam inhibitors / $\beta$-lactamases (16).

For the phenotypic detection of Extended spectrum beta-lactamases (ESBL) production, the enterobacteria was isolated and submitted to the approach disk technique, modified using the methodology described by Jarlier et al. (17).

For the phenotypic detection of AmpC-type beta-lactamase, the induction test was performed using antimicrobial susceptibility testing, was performed by the disk diffusion assay (Kirby-Bauer technique) according to the 2015 European Committee on Antimicrobial Susceptibility Testing (EUCAST) recommendations (18).

Imipenem and meropenem discs were used for the phenotypic investigation of carbapenemases and the interpretation of the sensitivity following the criteria established by CLSI (16). At least one bacteria that showed resistance of the carbapenems were submitted to the MBL screening test, using the enzyme blockade method and following the recommendations of ANVISA (18). The test used imipenem $(10 \mu \mathrm{g})$ and meropenem $(10 \mu \mathrm{g})$ disc, positioned parallel to two other imipenem and meropenem discs added with 10 $\mu \mathrm{L}$ of EDTA.

For enterobacteria, in addition to the EDTA test, the modified Hodge test (MHT) was also performed. MHT consists of the inoculation of E. coli ATCC $25922 \AA$ on the entire surface of a Müller-Hintos agar plate. A meropenem disk was placed in the center of the plate and around this disk streaks were made with the suspected samples, as recommended by CLSI (16). 
For each bacterium, plasmid extraction was done according to the FLEXIPREP extraction kit manual from Pharmacia ${ }^{\circledR}$, according to the manufacturer's instructions. For the qPCR assays, specific primers were designed based on the sequences deposited in GenBank (Table 1).

Reactions were prepared using the Sybr Green (Sybr Green qPCR master mix LOWROX - 100 reactions x 25 uL) Real Time PCR kit, following methodology suggested by the manufacturer. For the positive and endogenous control of the reaction the primers were used to amplify the 16S RNA, for the negative control, water was added in place of the DNA. Fisher's test was used to compare the techniques considering isolated samples.

Purified plasmid DNA preparations were digested with restriction enzymes for identification and characterization of the genes of that study according to the preparation: in microcentrifuge tubes were added: $2 \mu$ of 10x Buffer (Ludwigbiotec), (Buffer EcoR I for enzyme EcoR I and Buffer V2 for Hind III); $1 \mu \mathrm{l}$ of EcoR I or Hind III enzyme (10 UI / $\mu \mathrm{L}$ ) (Ludwigbiotec), $15 \mu \mathrm{L}$ H2O; $2 \mu \mathrm{l}$ template DNA ( 300 ng / $\mu \mathrm{l})$. The tubes were placed in thermoblocks at $37^{\circ} \mathrm{C}$ overnight and were then incubated at $-20^{\circ} \mathrm{C}$ for 15 minutes. From these preparations agarose gel electrophoresis was performed, as controls were used the preparation without the enzyme and a non-incubated preparation.

\section{Results}

The enterobacteria from this study were isolated from samples collected in four different types of origin. Among the total bacterial isolates, $40 \%$ are from human clinic, $20 \%$ from animal clinic, $10 \%$ from human hospital environment and $30 \%$ from veterinary hospital environment.

This study of antimicrobial resistance in enterobacteria characterized a phenotypic profile of resistance to beta-lactam antibiotics, in which among the 70 bacterial samples studied, 52 (74.28\%) were resistant to ampicillin, 44 (62.85\%) were resistant to amoxicillin associated with the beta-lactamase inhibitor clavalunate, 38 (54.28\%) were resistant to cefazolin, and 6 (8.57\%) were resistant to cefuroxime. The Table 2 shows the percentage of antimicrobial resistance by sample source of Enterobacteriaceae.

Phenotypically, through the antibiogram method, the species $E$. aerogenes, E. agglomerans and $C$. neteri stand out exhibiting the highest rate of resistance, being resistant to 10 of the 11 antibiotics tested $(90.9 \%)$.

The MDR, XDR and PDR profiles, found phenotypically in this study, determined that among the enterobacteria studied here there was a predominance of $68.57 \%$ XDR profiles, in which there was sensitivity to at least two groups among the four that form the $\beta$ - lactams. These data can be observed in Figure 1.

Fortunately no PDR profile was found because no bacteria were resistant to all antibiotics but because the acquisition of antimicrobial resistance is a natural phenomenon and can be accentuated by other factors, it should not be ruled out that they may present new profiles in the future including the PDR profile.

Still on the phenotypic profiles, it was observed that $28.57 \%$ were MDR and that the penicillin group was the antibiotic for which there was the highest resistance rate. There was resistance to at least one of the penicillins studied here in approximately $85.71 \%$ of the bacteria. For cephalosporins, there was resistance to at least one of those tested here in $77.14 \%$ of bacteria, a relatively high number demonstrating that such drugs, from the first to the fourth generation, are also losing their effect on enterobacteria.

In relation to $\beta$-lactams used as drugs of last resource- carbapenems - in this study there was phenotypic resistance to imipenem in $35.71 \%$ of the isolated bacteria. The antibiotic that presented the lowest percentage of resistance was the monobactam aztreonam with a resistance rate of $34.28 \%$, which corresponds to a rate close to that of carbapenems, showing that these antibiotics were the most effective against most bacterial samples studied.

The specie E. agglomerans showed phenotypic resistance data with profiles ranging from completely sensitive to XDR. This shows that within a same bacterial specie the resistance possibilities are very variable.

Following the analyzes of the results of this work, the mechanism of greatest strength that has been the ESBL (17.14\%), while the others were: AmpC (4.2\%), MBL (1.4\%) and Carbapenemase (0\%). The specie Y. ruckeri, was the one that promoted more number of mechanisms (ESBL, MBL and AmpC). The species that did not present any of the mechanisms were: E. blattae, H. alvei, R. terrigena and C. freundii.

The percentages of amplification of the beta-lactamase genes, through the qPCR method, found among Enterobacteriaceae were: $66.66 \%$ for the blaGIM and blaSIM genes, $61.11 \%$ for the blaDHA and blaTEM genes, 55.55\% for the blaCMY, blaCTX-M, blaNDM, blaOXA genes,

Page $4 / 16$ 
$50 \%$ for the blalMP gene, $44.44 \%$ for the blaSHV and blaSPM genes, $38.88 \%$ for the blaKPC gene, $33.33 \%$ for the blaSME gene and $16.66 \%$ for the blaVIM gene.

The fenotypic profile of resistance to beta-lactam antimicrobials was determined in 19 bacterial species among enterobactérias: among all the phenotypic resistances found, the species $E$. aerogenes, $E$. agglomerans, $C$. freundii and $C$. neteri, stood out showing the highest resistance rate $(90.9 \%)$. The molecular profile of resistance to beta-lactam antimicrobials was determined in 18 bacterial species among enterobacteria: $94.44 \%$ showing resistance for aztreonam, ceftazidima, cefoxitin and piperacillin associated with beta-lactamase inhibitor tazobactam. Phenotypic and molecular data are compared in Table 4.

By analyzing the amplification rate of the genes that confer beta-lactam resistance and making an association of the same with the literature review carried out in this study, it was observed that the species that showed potential for resistance of a greater number of antibiotics were: E aerogenes, R. terrigena, M. morganii, E. ictaluri, C. neteri, S. paratyphi and Y. ruckeri.,, exhibiting resistance potential for all antibiotics (100\%) tested. C. freundii, Klebsiella spp., E. coli, E blattae, P. rustigiani and E. persicina were studied, showing resistance potential for 10 of the 11 antibiotics $(90.9 \%)$ tested.

The resistance information obtained in this study shows that $100 \%$ of the analyzed species present a high potential for resistance to several beta-lactams. Among the potential profiles suggested by the qPCR analyzes, the XDR and PDR data were, respectively, $67,14 \%$ and $32,8 \%$ among the studied species. These data can be observed in Figure 1.

In molecular analyzes, PDR should be considered. The rate found for these pages was $38.88 \%$ and, although not very high, has repercussion on the degree to a clinical problem that may represent for the population.

The Pearson coefficient was calculated to linearly correlate two variables. The Pearson correlation coefficient varies between -1 and 1 . The signal indicates the direction of correlation (negative or positive) while the value indicates the magnitude. The closer to 1 the stronger the level of linear association between variables 3 .

In this study the detection rate of antimicrobial resistance by molecular methodology was generally higher than the detection rate by phenotypic methodology. But as already mentioned, the mere presence of the resistance gene in the bacterial genome does not necessarily imply its expression, and the phenotypic methodology is still necessary.

Were done a experiment to verify the plasmid perfil, and from plasmid DNA digested were no identifyed sites to EcoR I and Hind III restriction enzymes. After these results the authors decided that the best experiment to observe the restriction plasmid profile must be the sequencing experiments that will be done in another study.

\section{Discussion}

The phenotypical results of the present study are in agreement with a retrospective study that was carried out in a laboratory of clinical analyzes of Goiânia, Goiás, which evaluated the prevalence and antimicrobial susceptibility profile of the isolated microorganisms from 432 samples, in which the species E. aerogenes, E. agglomerans and $C$. neteri are related among those that present resistance to multiple drugs (20).

With the exception of $C$. neteri, which is a strain of animal origin, these bacterial species are in accordance with epidemiological data indicated by ANVISA (19), as they are among the species of enterobacteria most prevalent in primary bloodstream infections associated with the use of catheters in hospitalized patients in adult, pediatric and neonatal ICUs in Brazil.

About multidrug resitance (MDR), extremedrug resistance (XDR) and pandrug resistance (PDR) profiles have recently been updated by the CDC (Center for Disease and Control) and ECDC (European Center for Diasses Control and Prevention), promoted with the objective of international standardization of these terminologies, as published by Magiorakus et al., (20), in which, MDR was defined as the resistance to at least one agent in three or more categories of antimicrobials, XDR is resistance to at least one agent, including all categories, and PDR is resistance to all agents in all categories of antimicrobials.

According with authors, Enterobacteria resistant to carbapenems typically have XDR phenotypes and infections are associated with high mortality rates (up to 70\%), making them particularly challenging from a clinical standpoint (7).

A study corroborates with our data: it was analyzed the epidemiology of IPCSL and the sensitivity profile of the microorganisms of the State of Goiás in 2016, percentages on resistance were: $75 \%$ Enterobacter spp. resistant to cephalosporins of $4^{\text {th }}$ generation, $50 \%$ of $E$. coli 
resistant to carbapenems and to cephalosporins of $3^{\text {rd }}$ and $4^{\text {th }}$ generation; $28.6 \%$ of carbapenem resistant $K$ pneumoniae and $3^{\text {rd }}$ and $4^{\text {th }}$ generation cephalosporins and $42.9 \%$ resistant to $3^{\text {rd }}$ and $4^{\text {th }}$ generation cephalosporins, in addition to $50 \%$ of Serratia spp. resistant to the $3^{\text {rd }}$ and $4^{\text {th }}$ generation cephalosporins; differing from national results (23). Carbapenem-resistant enterobacteria have emerged as a major cause of nosocomial infections worldwide and are characterized by rapid and progressive dissemination (24).

In a study of carbapenem-resistant enterobacterial isolates (CRE) isolated from patients who received medical care at Stanford Health Care and Lucille Packard Children's Health, California, USA, between January 2013 and December 2016, as carbapenem minimum inhibitory concentration (MICs) for the CRE card ranged from $\leq 1$ to $265>8 \mu \mathrm{g} / \mathrm{mL}$ for imipenem, which also demonstrated increased resistance to this antimicrobial (25).

A study carried out in northeastern Brazil showed that in 672 urocultures positive for urinary tract infection, the etiological agent belonged to the Enterobacteriaceae family in $86.9 \%$, and among them 29 (4.8\%) were ESBL (26).

A literature review was carried out to determine the potential of resistance by molecular methodology found in this study, which has genes described in the literature that encode the $\beta$-lactamase enzyme. The result of the literary survey is shown in Table 3 (27-93).

In a study carried out with clinical isolates of carbapenem-resistant Enterobacteriaceae collected at the University Hospital of Santa Maria, Rio Grande do Sul, Brazil, the blaKPC, blaOXA-48, blaNDM, blaSPM, blaIMP, blaVIM and blaGIM genes were investigated by PCR and multiplex PCR. About the number of studied microorganisms, the genotypic tests evidenced that blaKPC was the most encountered gene, in $31 \%(n=10)$ of the samples, followed by blalMP, in $12.5 \%(n=4)(94)$.

In a study conducted in eight hospitals in the Paris region of France, twelve isolates were collected in twelve patients, $11 \mathrm{~K}$. pneumoamiae and 1 K. oxytoca. All isolates showed blaDHA gene and (4/12) 33.33\% blaTEM gene (95).

In another study, a total of 88 phenotypically ESBLs positive isolates from samples colleted from hospitals located in Mizoram, India, enterobacteria such as E. coli, K. pneumoniae and Salmonella spp. were isolated. All the isolates were tested for the presence of blaCTXM-1 and/or blaSHV genes by PCR assay. A total of 54 (13.04\%) isolates carried at least one ESBLs genes tested under this study, of which 41 (9.90\%) E. coli, 11 (2.66\%) K. pneumoniae and 2 (0.48\%) Salmonella were found to be positive for blaCTX-M-1/blaSHV gene. A total of $4(10.14 \%)$ and $9(2.17 \%)$ isolates were positive for blaCTX-M-1 and blaSHV genes, respectively, whereas, $3(0.72 \%) \mathrm{K}$. pneumoniae isolates were positive for both the genes. On the other hand, only $2(0.48 \%)$ Salmonella isolates for blaCTX-M-1 gene (96).

In our study, both rates are lower than those found in the phenotypic profile, however, it must be taken into account that the molecular analysis was performed in only 18 representatives of the studied species, thus presenting a smaller sample than the phenotypic tests. This fact explains why the data from the molecular analyzes are denominated only as potential and also, in addition, the presence of genes in the genome does not necessarily imply phenotypic expression of them (97).

Even molecular analyzes genes are not expressed as host carriers, the only fact of being present in circulating strains is already a high risk, since the onset and spread of the microorganism with drug resistance represents the problem of the interaction of several factors such as an exchange of genetic information between microorganisms, with transfer of genes to new hosts (98).

The presence of PDR profiles in the molecular analyzes and the absence of this profile in the phenotypic analyzes evidences the greater sensitivity of the molecular methodology. The main advantage of QPCR is that it provides a high and fast transfer rate of detection and quantification of target DNA sequences in different matrices. The low amplification time is facilitated by the simultaneous amplification and visualization of the new amplicons formed. However, the mere presence of genes responsible for components of antimicrobial resistance or toxin production does not automatically signify their expression or production (97). Thus, although molecular techniques are very useful, particularly for rapid results, they should be confirmed with standard phenotypic sensitivity tests (99).

Were done the statistic method and according with results of this study the closer to zero, the lower the association level (100). The low linear correlation found in this study $\left(r^{2}=0.0015\right.$ or $\left.r=0.038\right)$ should be understood as a comparative analysis of the efficiency of the two methodologies for the detection of antimicrobial resistance. The molecular methodology, PCR, is appreciated due to its high capacity of sensitivity and specificity (101). The low linear correlation found with the Pearson coefficient in this study evidences limitations of the phenotypic methodology and shows greater sensitivity of the molecular methodology for the detection of antimicrobial resistance.

However, it should be borne in mind that the conditions offered in culture media diverge from the actual conditions of a host organism. Since the culture medium is a favorable environment for bacterial growth, it offers optimal conditions for bacterial metabolism, a fact that does not occur in the host organism. This variation of conditions may be determinant for gene regulation, generally leading to the

Page 6/16 
expression of a greater number of genes in the environment of metabolic stress or gene suppression in environment with favorable growth conditions. This explains why the molecular data found here is compatible with epidemiological data (21).

\section{Conclusion}

This study demonstrated that levels of enterobacteria resistant to various antimicrobials are high, both in human and animal clinics. The present antimicrobial resistance study characterized phenotypic and molecular profiles of resistance to beta-lactam antibiotics in enterobacteria. The phenotypic profile was demonstrated by the Antimicrobial Sensitivity Test, performed by plate-diffusion (antibiogram), while the molecular profile was demonstrated from the Molecular Resistance Potential analyzes, which associates data from the literature review with the amplifications by quantitative PCR. MDR, XDR and PDR profiles were found. Being the PDR profile found only by molecular methodology. In this characterization, the detection rate by molecular methodology was higher, demonstrating the greater sensitivity of this technique.

According to the results obtained here, it can be determined that in view of the need for faster diagnosis in emergencies or not, the molecular method, because it is more sensitive, faster and less laborious, can be considered superior to the phenotypic method that presents some limitations such as: reproduction dependence of specific conditions for optimal growth of bacteria, detection of only cultivable organisms, previous preparation of material, greater manipulation and risk of contamination, more time for the final diagnosis.

\section{Declarations}

- Ethics and consent to participate

Not applicable.

- Declaration for publication

- Not applicable

- Declaration for availability of data and materials

The authors declare agree to make data and materials available to the BMC journal.

- Declaration of competing interest

The authors declare that the manuscript have no competing of interest in this section.

- Declaration for funding

The authors declare did not receive any specific grant from funding agencies in the public, commercial, or not-for-profit.

- Declaration of auhors'contributions

The authors declare the contribution declaration of each authors for the manuscript are:

APS: Has done substantial the acquisition, analysis, interpretation of data; wrote the paper and revised it substantively.

ALS: Has done substantial contribution for the acquisition, analysis, interpretation of data.

CZO: Has done substantial contributions for the conception of the work.

CRMI: Has done substantial for the acquisition of data.

JAA: Has done substantial for the acquisition of data.

MABCJ: Has done substantial for the acquisition of data.

MAP: Has done substantial for the acquisition of data.

MAGA: Has done substantial for the acquisition of data.

IJW: Has done substantial for the acquisition of data. 
GPLAG: Has done substantial for the acquisition of data.

ACSS: Has done substantial for the acquisition of data.

LSNOLV: Has done substantial for the acquisition of data.

MOS: Has done substantial for the acquisition of data.

CASBB: Has done substantial for the acquisition and analysis of data.

MSB: Has done substantial for the paper review.

LCC: Has done substantial for the acquisition, analysis, interpretation of data; wrote the paper and revised it substantively.

- Declaration of Acknowledgment

Not applicable.

\section{References}

1. Mlaga KD, Lotte R, Montaudié H, Rolain J-M, Ruimy R. 'Nissabacter archeti' gen. nov., sp. nov., a new member of Enterobacteriaceae family, isolated from human sample at Archet 2 Hospital, Nice, France. New Microbe and New Infect. 2017;17:81-83.

2. Winn WC, Allen SD, Janda WM, Koneman S. Diagnóstico Microbiológico: Texto e Atlas colorido. Guanabara Koogan. 2008;16:1-1760.

3. Coque T, Baqueiro F, Canton R. Increasing prevalence of ESBL- producing Enterobacteriaceae in Europe. Eurosurveillance. 2008;13:111.

4. Lutgring JD \& Limbagob BM. The Problem of Carbapenemase-Producing-Carbapenem-Resistant Enterobacteriaceae Detection. Journal of Clinical Microbiology. 2016;54:529-534.

5. Vega S \& Dowzicky MJ. Antimicrobial susceptibility among Gram-positive and Gram-negative organisms collected from the Latin American region between 2004 and 2015 as part of the Tigecycline Evaluation and Surveillance Trial. Annals of Clinical Microbiology and Antimicrobials. 2017;16:1-16.

6. Ozsurekci Y, Aykac K, Cengiz AB, TanırBasaranoglu S, Sancak B, Karahan S, Kara A, Ceyhan M. Bloodstream infections in children caused by carbapenem-resistant versus carbapenem-susceptible gram-negative microorganisms: Risk factors and outcome. Diagnostic Microbiology and Infectious Disease. 2017;87:359-364.

7. Rossoline GM, Arena F, Pecile P, Pollini S. Update on the antibiotic resistance crisis. Current Opinion in Pharmacology. 2014;18:56-60.

8. Levy SB \& Marshall B. Antibacterial resistance worldwide: causes, challenges and responses. Nature Medicine Supplement. 2004;10:122-129.

9. Koraimann G. Spread and Persistence of Virulence and Antibiotic Resistance Genes: A Ride on the F Plasmid Conjugation Module. EcoSal Plus. 2018;8:1-23.

10. Chant C, Leung A, Friedrich JO. Optimal dosing of antibiotics in critically ill patients by using continuous/extended infusions: a systematic review and metaanalysis. Critical care. 2013;17:R279.

11. Martínez-Martínez L \& Gonzáles-López JJ. Carbapenemases in Enterobacteriaceae: Types and molecular epidemiology. Enfermedades Infecciosas y Microbiologia Clinica. 2014;32:4-9.

12. Bertoncheli CDM, Hörner R. Uma revisão sobre metalo-ß-lactamases. Revista Brasileira de Ciências Farmacêuticas. 2008;44: 577599.

13. Lekshmi PNCJ, Sumi B, Viveka S, Jeeva S, Brindha R. Antibacterial activity of nanoparticles from Allium sp. Journal of Microbiology and Biotechnology Research. 2012;2:115-119.

14. Balouiri MS, Moulay I, Saad K. Methods for in vitro evaluating antimicrobial activity: A review. Journal of Pharmaceutical Analysis. 2016;6:71-79.

15. Tuite N, Reddington K, Barry T, Zumla A, Enne V. Rapid nucleic acid diagnostics for the detection of antimicrobial resistance in Gramnegative bacteria: Is it time for a paradigm shift. Journal of Antimicrobial Chemotherapy. 2014;69:1729-1733.

16. Clinical and Laboratory Standards Institute. Performance Standards for Antimicrobial Susceptibility Testing - Informational Supplement M100-S22. CLSI. 2017. Versão 27. 
17. Jarlier V; Nicolas MH; Fournier G; Philippon A. Extended broad-spectrum $\beta$-lactamases conferring transferable resistance to newer $\beta$ lactam agents in Enterobacteriaceae: hospital prevalence and susceptibility patterns. Review of Infectious Diseases. 1988;10:867878.

18. Brazilian Committe on Antimicrobial Susceptibility Testing. Orientações do EUCAST para a detecção de mecanismos de resistência e resistências específicas de importância clínica e/ou epidemiológica. 2015. EUCAST. Versão 1.0. Available in: http://brcast.org.br/documentos

19. Agência Nacional de Vigilância Sanitária. 2013. Nota Técnica Nº 01/2013:Medidas de Prevenção e Controle de Infecções por Enterobactérias Multiresistentes.

20. Jabur APL; Magalhães LG; Borges AA; Cardoso AL. Uroculturas de crianças atendidas em um laboratório de análises clínicas de Goiânia-GO ente 2012 e 2013. Estudos. 2014;41.

21. Agência Nacional de Vigilância Sanitária. Boletim de Segurança do Paciente e Qualidade em Serviços de Saúde $n^{\circ} 16$ (corrigido), 2017. Avaliable in: https://www20.anvisa.gov.br/segurancadopaciente/index.php/publicacoes/item/boletim-seguranca-do-pacientee-qualidade-em-servicos-de-saude-n-16-avaliacao-dos-indicadores-nacionais-das-infeccoes-relacionadas-a-assistencia-a-saude-irase-resistencia-microbiana-do-ano-de-2016. Acess in 19 set. 2018.

22. Magiorakos A, Srinivasan A, Carey RB, Carmeli Y, Falagas ME, Giske CG, Harbarth S, Hindler JF, Kahlmeter G, Olsson-Liljequist B, Patersin DL, Ricel LB, Stelling J, Struelens MJ, Vatopoulos A, Weber JT, Monnet DL. Bacteria: an International Expert Proposal for Interim Standard Definitions for Acquired Resistance. Microbiology. 2011;18:268-281.

23. Lopes LKO, Brito RMM, Lima MCG, Lopes LKO. Epidemiologia da infecção primária de corrente sanguínea laboratorial em unidade de terapia intensiva neonatal do estado de Goiás. Journal of Infection. 2011;7.

24. Lavagnoli LS, Bassetti BR, Kaiser TDL, Kutz KM, Junior CC. Factors associated with acquisition of carbapenem-resistant Enterobacteriaceae. Revista Latino-Americana de Enfermagem. 2017;25:1-7.

25. Secchyna F, Gaur R, Sandlund J, Truong C, Tremintin G, Küeltz D, Gomez C, Tamburini FB, Andermann TM, Bhatt A, Tickler IA, Watz N, Budvytiene I, Shi G, Tenover FC, Banaei N. Diverse Mechanisms of Resistance in Carbapenem-Resistant Enterobacteriaceae at a Health Care System in Silicon Valley, California. BioRxiv.2018; doi: 10.1101/298513

26. Neto MAR; Rios VM; Corá LF; Fonseca MM; Ferreira-Paim K; Fonseca FM. High rates of antimicrobial resistance of ESBL-producing Enterobacteriaceae isolated from clinical samples in Northeast of Brazil. Infectious Diseases. 2018;50:229-231.

27. Wendel AF, Brodner AHB, Wydra S, Ressina S, Henrich B, Pfeffer K, Toleman MA, MacKenziea CR. Genetic Characterization and Emergence of the Metallo- $\beta$-Lactamase GIM-1 in Pseudomonas spp. and Enterobacteriaceae during a Long-Term Outbreak. Antimicrobial Agents and Chemotherapy. 2013;57:5162-5165.

28. Pfeifer Y, Cullik A, Witte W. Resistance to cephalosporins and carbapenems in Gram-negative bacterial pathogens. International Journal of Medical Microbiology. 2010;300:371-379.

29. Verdet C, Benzerara Y, Gautier V, Adam O, Ould-Hocine Z, Arlet G. Emergence of DHA-1-Producing Klebsiella spp. in the Parisian Region: Genetic Organization of the ampC and ampR Genes Originating from Morganella morganii. Antimicrobial Agents and Chemotherapy. 2006;50:607-617.

30. Kjeldsen TSB, Overgaard M, Nielsen SS, Bortolaia V, Jelsbak L, Sommer M, Guardabassi L and Olsen JE. CTX-M-1 $\beta$-lactamase expression in Escherichia coli is dependent on cefotaxime concentration, growth phase and gene location. Journal Antimicrobial Chemotherapy. 2015;70:62-70.

31. Warjri I, Dutta TK, Lalzampuia H, Chandra R. Detection and characterization of extended-spectrum $\beta$-lactamases (blaCTX-M-1 and blaSHV) producing Escherichia coli, Salmonella spp. and Klebsiella pneumoniae isolated from humans in Mizoram. Veterinary World. 2015;8:599-604.

32. Machuca J, Agüerob J, Mirób E, Conejob MC, Oteob J, Boub G, González-Lópezb JJ, Oliverb A, Navarrob F, Pascuala A, MartínezMartínez L. Prevalencia en España de mecanismos de resistencia a quinolonas enenterobacterias productoras de betalactamasas de clase C adquiridasy/o carbapenemasas. Enfermedades Infecciosas y Microbiología Clínica. 2017;35: 487-492.

33. Pietscha M, Eller C, Wendtc C, Holfelderc M, Falgenhauerd L, Fruthe A, Grössla T, Leistnerf R, Valenzag G, Wernera G, Pfeifera Y, RESET Study Group. Molecular characterisation of extended-spectrum $\beta$-lactamase (ESBL)-producing Escherichia coli isolates from hospital and ambulatory patients in Germany. Veterinary Microbiology. 2017; 200:130-137.

34. Wang L, Liu P, Wei D, Liu Y, Wan L, Xiang T, Zhang Y. Clinical isolates of uropathogenic Escherichia coli ST131 producing NDM-7 metallo- $\beta$-lactamase in China. International Journal of Antimicrobial Agents. 2016;48:41-45. 
35. Bush K. A resurgence of -lactamase inhibitor combinations effective against multidrug-resistant Gram-negative pathogens. International Journal of Antimicrobial Agents. 2015;46:483-493.

36. Yang H, Chen H, Yang Q, Chen M, Wang H. High Prevalence of Plasmid-Mediated Quinolone Resistance Genes qnr and aac(6)-Ib-cr in Clinical Isolates of Enterobacteriaceae from Nine Teaching Hospitals in China. Antimicrobial Agents and Chemotherapy. 2008;52:4268-4273.

37. Yong D, Toleman MA, Giske CG, Cho HS, Sundman K, Lee K, Walsh TR. Characterization of a New Metallo-Lactamase Gene, blaNDM-1, and a Novel Erythromycin Esterase Gene Carried on a Unique Genetic Structure in Klebsiella pneumoniae Sequence Type 14 from India. Antimicrobial Agents and Chemotherapy. 2009;53:5046-5054.

38. Sampaio JLM \& Gales AC. Antimicrobial resistance in Enterobacteriaceae in Brazil: focus on $\beta$-lactams and polymyxins. Brazilian Journal of Microbiology. 2016;47S:31-37.

39. Singh-Moodley A \& Perovic 0 . Antimicrobial susceptibility testing in predicting the presence of carbapenemase genes in Enterobacteriaceae in South Africa. BioMed Central Infectious Diseases. 2016;16:1-10.

40. Magagnin CM, Rozales1 FP, Antochevis L, Nunes LS, Martins AS, Barth AL, Sampaio JM,Zavascki AP. 2017. Dissemination of blaOXA-370 gene among several Enterobacteriaceae species in Brazil. European Journal Clinical Microbiology Infection Diseases. 2017;36:1907-1910.

41. Kayama S, Ohge H, Sugai M. Rapid discrimination of blalMP-1, blalMP-6, and blalMP-34 using a multiplex PCR. Journal of Microbiological Methods. 2017;135:8-10.

42. Duin DV \& Doi Y. The global epidemiology of carbapenemaseproducing Enterobacteriaceae. Virulence. 2017;8:460-469.

43. Jeong SH, Kim H, Kim J, Shin DH, Kim HS, Park M, Shin S, Hong JS, Lee SS, Song W. Prevalence and Molecular Characteristics of Carbapenemase-Producing Enterobacteriaceae From Five Hospitals in Korea. Annals of Laboratory Medicine. 2016:529-535.

44. Ingti B, Paul D, Maurya AP, Bora D, Chanda DD, Chakravarty A, Bhattacharjee A. 2017. Occurrence of blaDHA-1 mediated cephalosporin resistance in Escherichia coli and their transcriptional response against cephalosporin stress: a report from India. Annals of Clinical Microbiology and Antimicrobials. 2017;16:1-8.

45. Srisrattakarn A, Lulitanond A, Wilailuckana C, Charoensri N, Wonglakorn L, Saenjamla P, Chaimanee P, Daduang J, Chanawong A. Rapid and simple identification of carbapenemase genes, blaNDM, blaOXA-48, blaVIM, blaIMP-14 and blaKPC groups, in Gramnegative bacilli by in-house loop-mediated isothermal amplification with hydroxynaphthol blue dye. World Journal Microbiology Biotechnology. 2017;33:130-140.

46. Ayala AT, Acuña HMB, Calvo MTA, Morales JLV, Chacón EC. Emergencia de $\beta$-lactamasa AmpC plasmídica del grupo CMY-2 en Shigella sonnei y Salmonella spp. en Costa Rica, 2003-2015. Pan American Journal of Public Health. 2016;40:70-75.

47. Suwantarat N, Logan LK, Carroll KC, Bonomo RA, Simner PJ, Rudin SD, Milstone AM, Tekle T, Ross T, Tamma PD. The Prevalence and Molecular Epidemiology of Multidrug-Resistant Enterobacteriaceae Colonization in a Pediatric Intensive Care Unit. Infection Control Hospital Epidemiology. 2016;37:535-543.

48. Silva KC \& Lincopan N. Epidemiologia das betalactamases de espectro estendido no Brasil: impacto clínico e implicações para o agronegócio. Journal Brazilian Patology Medicine Laboratory. 2012;48:91-99.

49. Li X, Plésiat P, Nikaidoc H. The Challenge of Efflux-Mediated Antibiotic Resistance in Gram-Negative Bacteria. Clinical Microbiology Reviews. 2015;28:337-418.

50. Bialvaei AZ, Kafil HS, Asgharzadeh M, Memar MY, Yousefi M. Current methods for the identification of carbapenemases. Journal of Chemotherapy. 2016;28:1-19.

51. Xia J, Gao J, Tang W. Nosocomial infection and its molecular mechanisms of antibiotic resistance. BioScience Trends. 2016;10:1421.

52. Jacoby GA. AmpC Beta-Lactamases. Clinical Microbiology Reviews. 2009:161-182.

53. Rood IGH \& Li Q. Review: Molecular detection of extended spectrum- $\beta$-lactamase- and carbapenemase-producing Enterobacteriaceae in a clinical setting. Diagnostic Microbiology and Infectious Disease. 2017;89:245-250.

54. Jones-Dias D, Manageiro V, Caniça M. Influence of agricultural practice on mobile bla genes: Incl1-bearing CTX-M, SHV, CMY and TEM in Escherichia coli from intensive farming soils. Environmental Microbiology. 2016;18:260-272.

55. Bush K. Overcoming ß-lactam resistance in Gram-negative pathogens. Future Medicinal Chemistry. 2016;8:921-924.

56. Bush K, Courvalin P, Dantas G, Davies J, Eisenstein B, Huovinen P, Jacoby GA, Kishony R, Kreiswirth BN, Kutter E, Lerner SA, Levy S, Lewis K, Lomovskaya O, Miller JH, Mobashery S, Piddock LJV, Projan S, Thomas CM, Tomasz A, Tulkens PM, Walsh TR, Watson JD, Witkowski J, Witte W, Wright G, Yeh Y, Zgurskaya HI. Tackling antibiotic resistance. Nature Reviews. 2011;9:895-896.

Page 10/16 
57. Bush K \& Jacoby GA. Updated Functional Classification of B-Lactamases. Antimicrobial Agents and Chemotherapy. 2010;54:969976.

58. Bush K. The ABCD's of b-lactamase nomenclature. Journal Infection Chemotherapy. 2013;19:549-559.

59. Page MGP \& Bush K. Discovery and development of new antibacterial agents targeting Gram-negative bacteria in the era of pandrug resistance: is the future promising? ScienceDirect. 2014;18:91-97.

60. Wei D, Wan L, Yu Y, Xu Q, Deng Q, Cao X, Liu Y. Characterization of Extended-Spectrum $\beta$-Lactamase, Carbapenemase, and Plasmid Quinolone Determinants in Klebsiella pneumoniae Isolates Carrying Distinct Types of 16S rRNA Methylase Genes, and Their Association with Mobile Genetic Elements. Microbial Drug Resistance. 2015;21:186-193.

61. Rocha DAC, Campos JC, Passadore LF, Sampaio SCF, Nicodemo AC, Sampaio JLM. Frequency of Plasmid-Mediated AmpC $\beta$ Lactamases in Escherichia coli Isolates from Urine Samples in São Paulo, Brazil. Microbial Drug Resistance. 2016;22:321-327.

62. Alekshun MN \& Levy SB. Molecular Mechanisms of Antibacterial Multidrug Resistance. Cell. 2007;128:1037-1050.

63. Brandt C, Braun SD, Stein C, Slickers P, Ehricht R, Pletz MW, Makarewicz O. In silico serine $\beta$-lactamases analysis reveals a huge potential resistome in environmental and pathogenic species. Nature. 2017;7:1-13.

64. Olsen I. New promising $\beta$-lactamase inhibitors for clinical use. European Journal Clinical Microbiology Infection Diseases 2015;34:1303-1308.

65. Lupo A, Papp-Wallace KM, Sendi P,Bonomo RA, Endimiani A. Non-Phenotypic Tests to Detect and Characterize Antibiotic Resistance Mechanisms in Enterobacteriaceae. Diagnostic Microbiology Infection Disease. 2013;77:179-194.

66. Diene SM \& Rolain J-M. Carbapenemase genes and genetic platforms in Gram-negative bacilli: Enterobacteriaceae, Pseudomonas and Acinetobacter species. Clinical Microbiology Infection 2014;20:831-838.

67. Poirel L, Wenger A, Bille J, Bernabeu S, Naas T, Nordmann P. SME-2-Producing Serratia marcescens Isolate from Switzerland. Antimicrobial Agents and Chemotherapy. 2007;51:2282-2283.

68. Queenan AM \& Bush K. Carbapenemases: the Versatile -Lactamases. Clinical Microbiology Reviews. 2007;20:440-458.

69. Wendel AF, Brodner AHB, Wydra S, Ressina S, Henrich B, Pfeffer K, Toleman MA, MacKenziea CR. Genetic Characterization and Emergence of the Metallo- $\beta$-Lactamase GIM-1 in Pseudomonas spp. and Enterobacteriaceae during a Long-Term Outbreak. Antimicrobial Agents and Chemotherapy. 2013;57:5162-5165.

70. Meini M, Llarrull LI, Vila AJ. Overcoming differences: the catalytic mechanism of metallo- $\beta$-lactamases. FEBS Letters. 2015;589:3419-3432.

71. Mlynarcik P, Roderova M, Kolar M. Primer Evaluation for PCR and its Application for Detection of Carbapenemases in Enterobacteriaceae. Jundishapur Journal Microbiology. 2016;9:1-6.

72. Pascual A, Pintadoc V, Rodríguez-Bañoa J, Miró JM. Carbapenemase-producing Enterobacteriaceae: The end of the antibiotic era? Enfermedades Infecciosas y Microbiología Clínica. 2014;32:1-3.

73. Bonelli RR, Moreira BM, Picão RC. Antimicrobial resistance among Enterobacteriaceae in South America: History, current dissemination status and associated socioeconomic factors. Drug Resistance Updates. 2014;17:24-36.

74. Bratu S, Landman D, Haag R, Recco R, Eramo A, Alam M, Quale J. Rapid spread of carbapenem resistant Klebsiella pneumoniae in New York City: a new threat to our antibiotic armamentarium. Arch Intern Med. 2005;165:1430-5.

75. Bush K. Proliferation and significance of clinically relevant $\beta$-lactamases. Annals of the New York Academy of Sciences. 2013;1277:84-90.

76. Bush K \& Bradford PA. $\beta$-Lactams and $\beta$-Lactamase Inhibitors: An Overview. Cold Spring Harbor Perspectives in Medicine. 2016;6:122.

77. Bush K \& Pucci MJ. New antimicrobial agents on the horizon. Biochemical Pharmacology. 2011;82:1528-1539.

78. Clark JD, Catro JPF, Compton C, Lee H, Nunery W. Orbital cellulitis and corneal ulcer due to Cedecea: First reported case and review of the literature. Orbit. 2016;35:140-3.

79. Coque T, Baqueiro F, Canton R. Increasing prevalence of ESBL - producing Enterobacteriaceae in Europe. Eurosurveillance. 2008;13:111.

80. Cuzon G, Naas T, Correa A, Quinn JP, Villegas MV, Nordmann P. Dissemination of the KPC-2 carbapenemase in non-Klebsiella pneumoniae enterobacterial isolates from Colombia. International Journal of Antimicrobial Agent. 2013;42:59-62.

81. Falcone M, Mezzatesta ML, Perilli M, Forcella C, Giordano A. Infections with VIM-1 metallo ßlactamase-producing Enterobacter cloacae and their correlation with clinical outcome. Journal Clinical Microbiology. 2009;47:3514-9.

Page $11 / 16$ 
82. Gaynes R \& Edwards JR. Overview of Nosocomial Infections Caused by Gram-Negative Bacili. Clinical Infectious Diseases. 2005;41:848-54.

83. Heggendorm LH, Gomes SWC, Silva NA, Varges RG, Póvoa HCC. Epidemiological profile and antimicrobial susceptibility of microorganisms isolated from nosocomial infections. Revista Saúde e Meio Ambiente-RESMA. 2016;2:26-47.

84. Jácome PRLA, Alves LR, Jácome-Júnior AT, Silva MJB, Lima JLC, Araújo PSR, Lopes ACS, Maciel MAV. Detection of bla SPM-1, bla KPC, bla TEM and bla CTX-M genes in isolates of Pseudomonas aeruginosa, Acinetobacter spp. and Klebsiella spp. from cancer patients with healthcare-associated infections. Journal of Medical Microbiology. 2016;65:658-665.

85. Kordon AO, Abdelhamed H, Ahmed H, Park JY, Karsi A, Pinchuk LM. Phagocytic and bactericidal properties of channel catfish peritoneal macrophages exposed to Edwardsiella ictaluri live attenuated vaccine and wild-type strains. Frontiers in Microbiology. 2018;8:1-11.

86. Lavagnoli LS, Bassetti BR, Kaiser TDL, Kutz KM, Junior CC. Factors associated with acquisition of carbapenem-resistant Enterobacteriaceae. Revista Latino-Americana de Enfermage. 2017;25:1-7.

87. Manageiro V, Ferreira E, Rodrigues J, Sampaio DA, Vieira L, Pereira P, Rodrigues P, Palos C, Caniça M. NDM-1-producing Providencia stuartii isolates in a Portuguese Hospital. Réunion interciciplinaire de chimiothérapie anti-infectieuse. $2015 ; 35$.

88. Martínez-Martínez L \& Gonzáles-López JJ. Carbapenemases in Enterobacteriaceae: Types and molecular epidemiology. Enfermedades Infecciosas y Microbiologia Clinica. 2014;32:4-9.

89. Ozsurekci Y, Aykac K, Cengiz AB, TanırBasaranoglu S, Sancak B, Karahan S, Kara A, Ceyhan M. Bloodstream infections in children caused by carbapenem-resistant versus carbapenem-susceptible gram-negative microorganisms: Risk factors and outcome. Diagnostic Microbiology and Infectious Disease. 2017;87:359-364.

90. Pontes DS, Araujo RSA, Dantas N, Scott L, Scott MT, Moura RO, Mendonça-Junios FJB. 2018. Genetic Mechanisms of Antibiotic Resistance and the Role of Antibiotic Adjuvants. Current Topics in Medicinal Chemistry. 2018;18:42-74.

91. Rocha DAC, Campos JC, Passadore LF, Sampaio SCF, Nicodemo AC, Sampaio JLM. Frequency of Plasmid-Mediated AmpC $\beta$ Lactamases in Escherichia coli Isolates from Urine Samples in São Paulo, Brazil. Microbial Drug Resistance. 2016;22:321-327.

92. Souli M, Galani I, Antoniadou A, Papadomichelakis E, Poulakou G. An outbreak of infection due to $\beta$-lactamase Klebsiella pneumoniae carbapenemase 2-producing K. pneumoniae in a Greek University Hospital: molecular characterization, epidemiology, and outcomes. Clinical Infection Disease. 2010;50:364-73.

93. Sun F, Zhou D, Wang Q, Feng J, Feng W, Luo W, Zhang D, Liu Y, Qiul X, Yin Z, Chen W, Xia P. The first report of detecting the blaSIM2gene and determining the complete sequence of the SIM-encoding plasmid. Clinical Microbiology and Infection. 2016;22:347-351.

94. Toombs-Ruane LJ, Benschop J, Priest P, Murdoch DR, French NP. Multidrug resistant Enterobacteriaceae in New Zealand: a current perspective. New Zealand Veterinary Journal. 2017;65:62-70.

95. Wang Y, Jiang X, Xu Z, Ying C, Yu W, Xiao Y. Identification of Raoultella terrigena as a Rare Causative Agent of Subungual Abscess Based on 16S rRNA and Housekeeping Gene Sequencing. Canadian Journal of Infectious Diseases and Medical Microbiology. 2016;1:1-4.

96. Marques JB; Bonez PC; Agertt VA; Flores VC; Dalmolin TV; Rossi GG; Forno NLFD; Bianchini BV; Mizdal CR; Siqueira FS; Righi RA; Meneghetti BH; Trindade PA; Santos RCV; Campos MMA. Molecular characterization of Enterobacteriaceae resistant to carbapenem antimicrobials. Revista Brasileira de Patologia Médica Laboratorial. 2015;51:162-165.

97. Verdet C; Benzerara Y; Gautier V; Adam O; Ould-Hocine Z; Arlet G. Emergence of DHA-1-Producing Klebsiella spp. in the Parisian Region: Genetic Organization of the ampC and ampR Genes Originating from Morganella morganii. Antimicrobial Agents and Chemotherapy. 2006;50:607-617.

98. Warjri I; Dutta TK; Lalzampuia H; Chandra R. Detection and characterization of extended-spectrum $\beta$-lactamases (blaCTX-M-1 and blaSHV) producing Escherichia coli, Salmonella spp. and Klebsiella pneumoniae isolated from humans in Mizoram. Veterinary World. 2015;8:599-604.

99. Kralik P \& Ricchi M. A basic guide to real time PCR in microbial diagnostics: Definitions, parameters, and everything. Frontiers in Microbiology. 2017;8:1-9.

100. Stefaniak LA, Duarte EL, Nishiyama SAB, Nakano V. Resistência bacteriana: a importância das beta-lactamases. Revista UNINGÁ. 2005;4:123-137.

101. Álvarez LMA, García JMG, Hernández MDP, González SM, Gutiérrez JJP. Utility of Phenotypic and Genotypic Testing in the Study of Mycobacterium tuberculosis Resistance to First-Line Anti-Tuberculosis drugs. Archivos de Broncopneumologia. 2017;53:192-198. 
102. Filho DBF, Rocha EC, Júnior JAS, Paranhos R, Neves JAB, Silva MB. Desvendando os Mistérios do Coeficiente de Correlação de Pearson: O retorno. Leviathan - Cadernos de Pesquisa Política. 2014;8:66-96.

103. Rodrigues RL, Nascimento HF, Menezes GL, Lopes AR, Nevoa JC, Soares WCS, Santiago SB, Barbosa MS. Contribuição ao estudo comparativo do diagnóstico laboratorial clássico e molecular de Helicobacter pylori: uma abordagem investigativa. Revista Acadêmica do Instituto de Ciências da Saúde. 2016;2: 18-25.

\section{Tables}

Table 1. Oligonucleotides used for amplification of the $\beta$-lactam resistance genes of this study. 


\begin{tabular}{|c|c|c|c|c|c|}
\hline Genes & Gene sequence from $5^{\prime}$ to $3^{\prime}$ & Temperature of ringing & Quantity of & Access at the & Amplified fragment \\
\hline & & & bases & GenBank & Size \\
\hline \multirow[t]{2}{*}{ blaOXA } & Sense: GGCAGCGGGTTCCCTTGTC & 49,7 & 19 & FN396876.1 & $171 \mathrm{pb}$ \\
\hline & Reverso: CGATAATGGGCTGCAGCGG & 49,7 & 19 & & \\
\hline \multirow[t]{2}{*}{ blaIMP } & Sense: CCAGCGTACGGCCCACAGA & 49,6 & 19 & NG035455.1 & $138 \mathrm{pb}$ \\
\hline & Reverso: GGTGATGGCTGTTGCGGCA & 50,3 & 19 & & \\
\hline \multirow[t]{2}{*}{ blaNDM } & Sense: CGGCCGCGTGCTGGTG & 49,8 & 16 & JN711113.1 & $182 \mathrm{pb}$ \\
\hline & Reverso: GGCATAAGTCGCAATCCCCG & 50,2 & 20 & & \\
\hline \multirow[t]{2}{*}{ blaSME } & Sense: GGCGGCTGCTGTTTTAGAGAGG & 50,9 & 25 & KJ188748.1 & $184 \mathrm{pb}$ \\
\hline & Reverso: TGCAGCAGAAGCCATATCACCTAAT & 50,3 & 22 & & \\
\hline \multirow[t]{2}{*}{ blaDHA } & Sense: GCGGGCGAATTGCTGCAT & 49,8 & 18 & NG041043.1 & $183 \mathrm{pb}$ \\
\hline & Reverso: TGGGTGCCGGGGTAGCG & 50,1 & 17 & & \\
\hline \multirow[t]{2}{*}{ blaCMY } & Sense: GGATTAGGCTGGGAGATGCTGAA & 50,1 & 23 & NG041279.1 & $158 \mathrm{pb}$ \\
\hline & Reverso: CCAGTGGAGCCCGTTTTATGC & 49,6 & 21 & & \\
\hline \multirow[t]{2}{*}{ blaTEM } & Sense: TCCGTGTCGCCCTTATTCCC & 49,6 & 20 & KJ923009 & $165 \mathrm{pb}$ \\
\hline & Reverso: CCTTGAGAGTTTTCGCCCCG & 49,6 & 20 & & \\
\hline \multirow[t]{2}{*}{ blaSHV } & Sense: GGCAGCGGGTTCCCTTGTC & 49,7 & 19 & FN396876.1 & $171 \mathrm{pb}$ \\
\hline & Reverso: CGATAATGGGCTGCAGCGG & 49,7 & 19 & & \\
\hline \multirow[t]{2}{*}{ blaVIM } & Sense: GTTATGCCGCACCCACCCC & 50,3 & 19 & NG036099.1 & $194 \mathrm{pb}$ \\
\hline & Reverso: ACCAAACACCATCGGCAATCTG & 49,7 & 22 & & \\
\hline \multirow[t]{2}{*}{ blaSPM } & Sense: CGAAAATGCTTGATGGGACCG & 50,3 & 21 & DQ145284.1 & $147 \mathrm{pb}$ \\
\hline & Reverso: CACCCGTGCCGTCCAAATG & 49,7 & 19 & & \\
\hline \multirow[t]{2}{*}{ blaCTX } & Sense: CTGAGCTTAGCGCGGCCG & 50,1 & 18 & FJ815279.1 & $189 \mathrm{pb}$ \\
\hline & Reverso: AATGGCGGTGTTTAACGTCGG & 50,0 & 21 & & \\
\hline \multirow[t]{2}{*}{ blaGIM } & Sense: CGGTGGTAACGGCGCAGTG & 50,2 & 19 & JX566711.1 & $149 \mathrm{pb}$ \\
\hline & Reverso: TGCCCTGCTGCGTAACATCG & 50,2 & 20 & & \\
\hline \multirow[t]{2}{*}{ blaKPC } & Sense: GGCGGCTCCATCGGTGTG & 49,5 & 18 & AF297554.1 & $155 \mathrm{pb}$ \\
\hline & Reverso: GTGTCCAGCAAGCCGGCCT & 50,4 & 19 & & \\
\hline \multirow[t]{2}{*}{ blaSIM } & Sense: GCACCACCGGCAAGCGC & 50,8 & 17 & EF125010.1 & $156 \mathrm{pb}$ \\
\hline & Reverso: TGTCCTGGCTGGCGAACGA & 50,0 & 19 & & \\
\hline
\end{tabular}

Table 2 - Percentage of antimicrobial resistance by sample source (\%). 


\begin{tabular}{lcccccc}
\hline \multirow{2}{*}{ Antibiotics } & \multicolumn{6}{c}{ Percentage of antimicrobial resistance (\%) } \\
\cline { 2 - 7 } & $\begin{array}{c}\text { Manual } \\
\text { Resuscitators }\end{array}$ & $\begin{array}{l}\text { Human } \\
\text { cornea }\end{array}$ & $\begin{array}{c}\text { Human } \\
\text { tonsilas }\end{array}$ & $\begin{array}{c}\text { Veterinary } \\
\text { Hospital }\end{array}$ & $\begin{array}{c}\text { Animal } \\
\text { bladder }\end{array}$ & $\begin{array}{c}\text { Animal } \\
\text { uterus }\end{array}$ \\
\hline Ampicillin & 42.85 & 65.21 & 0.2 & 90.47 & 100 & 100 \\
\hline Aztreonam & 0 & 26.08 & 0 & 85.71 & 0 & 0 \\
\hline $\begin{array}{l}\text { Amoxicillin- } \\
\text { clavalunate }\end{array}$ & 0 & 39.13 & 0 & 90.47 & 100 & 100 \\
\hline Ceftazidime & 100 & 30.43 & 0 & 85.71 & 100 & 0 \\
\hline Cefoxitin & 42.85 & 39.13 & 0.2 & 76.19 & 0 & 0 \\
\hline Cefazolin & 0 & 52.17 & 100 & 80.95 & 100 & 0 \\
\hline Cefepime & 100 & 30.43 & 0 & 95.23 & 0 & 0 \\
\hline Ceftriaxone & 0 & 26.08 & 0 & 0 & 0 & 0 \\
\hline Cefuroxime & 100 & 26.08 & 0 & 76.19 & 0 & 0 \\
\hline Imipenem & 100 & 30.43 & 0.2 & 28.57 & 100 & 0 \\
\hline $\begin{array}{l}\text { Piperacillin- } \\
\text { tazobactam }\end{array}$ & 100 & 17.39 & 0 & 67.66 & 100 & 0 \\
\hline
\end{tabular}

Table 3: Bibliographical survey concerning the phenotypic resistance of betalactamases against the corresponding resistance genes. Subtitle: The (+) sign indicates correlation in the literature of the corresponding beta-lactamase coding gene of the column, with the corresponding antibiotic in the horizontal line. While the (-) sign indicates absence of correlation in the gene and antibiotic literature.

\section{Genes encoding beta-lactamase enzymes}

\section{Antimicrobials}

\section{Beta-lactams}

Ampicillin

Aztreonam

Amoxicillin +

Clavanulate

Ceftazidime

Cefoxitin

Cefazolin

Cefepime

Ceftriaxone

Cefuroxime

Imipenem

Piperacicllin +

Tazobactam

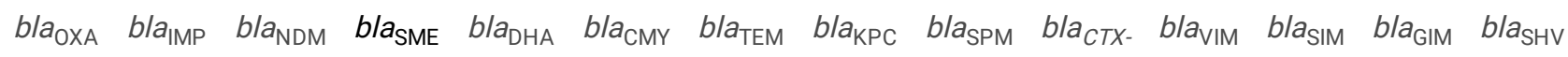 \\ bla $a_{\mathrm{OXA}}$ bla $a_{\mathrm{IMP}}$ bla $a_{\mathrm{NDM}}$ bla}

\begin{tabular}{|c|c|c|c|c|c|c|c|c|c|c|c|c|c|}
\hline- & - & - & + & - & + & - & + & + & - & - & + & - & - \\
\hline+ & - & + & - & - & - & + & + & + & + & + & + & - & + \\
\hline - & - & + & - & - & + & + & - & - & + & - & - & - & + \\
\hline+ & + & + & - & - & - & + & + & + & + & + & + & - & + \\
\hline - & - & + & - & - & + & + & - & + & + & - & - & - & - \\
\hline - & - & - & - & - & - & - & + & - & - & - & - & - & - \\
\hline+ & + & - & - & - & - & + & + & + & + & + & + & - & - \\
\hline - & - & - & - & - & + & + & + & - & + & - & - & - & + \\
\hline - & - & - & - & - & - & - & + & - & + & + & - & - & + \\
\hline+ & + & - & + & - & - & - & + & + & - & + & + & + & - \\
\hline & & - & - & - & + & + & + & + & + & + & + & - & + \\
\hline
\end{tabular}

Table 4: Rates of detection of phenotypic and molecular antimicrobial resistance. 


\begin{tabular}{cccccc}
\hline Antimicrobials & Molecular & Phenotypic & \multicolumn{3}{c}{ Descriptive statistics } \\
& detection rate (\%) & detection rate (\%) & Standard deviation & Default error & Variance \\
\hline Ampicillin & 83.33 & 74.28 & 6.39931637 & 4.525 & 40.95125 \\
\hline Aztreonam & 94.44 & 34.28 & 42.53954396 & 30.08 & 1809.6128 \\
\hline Amoxicilina + Clavalunate & 88.88 & 62.85 & 18.40599 & 13.015 & 338.7805 \\
\hline Ceftazidime & 94.44 & 51.42 & 30.41973 & 21.51 & 925.3602 \\
\hline Cefoxitine & 94.44 & 41.42 & 37.4908 & 26.51 & 1405.56 \\
\hline Cefazoline & 38.88 & 54.28 & 10.88944 & 7.7 & 118.58 \\
\hline Cefepime & 88.88 & 44.28 & 31.53696 & 22.3 & 994.58 \\
\hline Ceftriaxone & 88.88 & 41.42 & 33.55929 & 23.73 & 1126.226 \\
\hline Cefuroxime & 72.22 & 8.57 & 45.00735 & 31.825 & 2025.661 \\
\hline Imipenem & 88.88 & 35.71 & 37.59687 & 26.585 & 1413.524 \\
\hline Piperacillin + Tazobactam & 94.44 & 41.42 & 37.4908 & 26.51 & 1405.56 \\
\hline
\end{tabular}

\section{Figures}

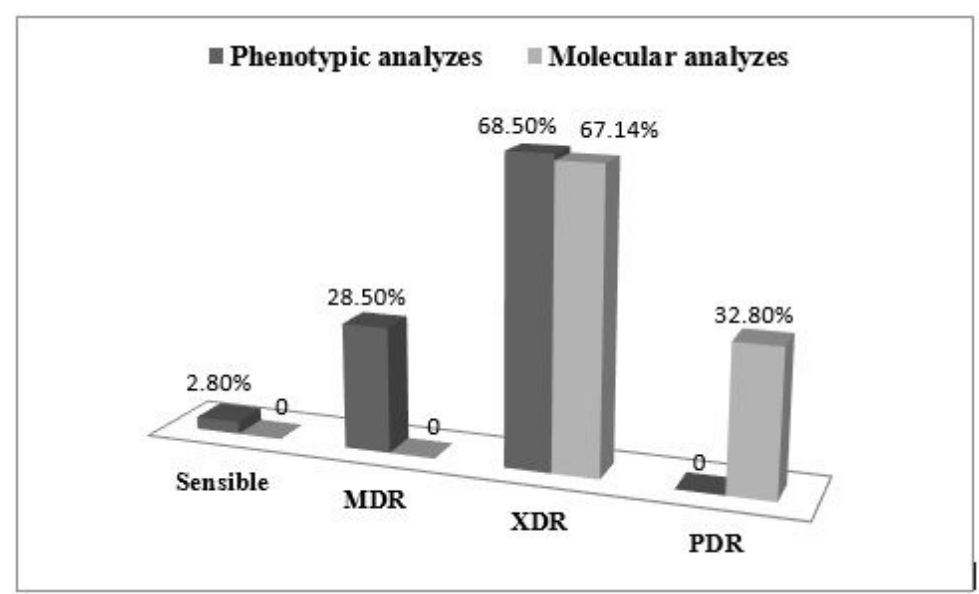

Figure 1

Percentage of Profiles of resistance in Enterobacteriaceae. 